\title{
A területi kutatásoktól a regionális tudományig Kelet- és közép-európai tudománytörténeti vázlat
}

\author{
From spatial research to regional science \\ A draft of Eastern and Central European science history
}

\author{
HORVÁTH GYULA
}

HORVÁTH Gyula: tudományos tanácsadó, MTA Közgazdaság- és Regionális Tudományi Kutatóközpont, Regionális Kutatások Intézete, Pécs; egyetemi tanár, Pécsi Tudományegyetem, Közgazdaságtudományi Kar; horvath@rkk.hu

KULCSSZAVAK: regionális tudomány, területi fejlődés, területi átalakulás - történelmi folyamatok, regionális tudomány - intézményrendszer, Kelet- és Közép-Európa

ABSZTRAKT: E tanulmány a volt szocialista blokk országainak regionális kutatási kapacitásait értékeli. Képet ad a területi kutatások történeti előzményeiről, a megoldandó regionális feladatok jellemzőiről, a regionális tudomány intézményesítésének sajátosságairól, a publikációs fórumokról. Végezetül összegzi a regionális tudomány különböző ismérveinek jelenlétét az egyes országokban. A rendszerváltozást követően a piacgazdaság kiépülése mély regionális átalakulást indított el. A változások irányíthatósága miatt természetes igényként fogalmazódott meg a területi kutatások tematikai és szervezeti fejlesztése. Az európai uniós csatlakozás előkészítése újabb impulzusokat adott a kutatásoknak. A 21. század elején valamennyi országban bővültek a regionális kutatás nemzeti műhelyei. A kutatások volumenét, intézményi berendezkedését és területi elhelyezkedését tekintve különbségek figyelhetők meg. Azt állapíthatjuk meg, hogy két uniós tagországban - Lengyelországban és Magyarországon -, valamint Oroszországban kellő mennyiségben fellelhetők mindazok az elemek, amelyek a regionális tudományt önálló tudományágazatként jelenítik meg. A többi országban a diszciplináris ismérvek egy része hiányzik vagy gyenge fejlettséget mutat.

Gyula HORVÁTH: scientific advisor, Institute for Regional Studies, Centre for Economic and Regional Studies, Hungarian Academy of Sciences, Pécs; professor, Faculty of Economics, University of Pécs; horvath@rkk.hu

KEYWORDS: regional science, regional development, spatial transformation - historical trends, regional science - institutional system, Eastern and Central Europe

ABSTRACT: The 20th century marked an era of specialisation of the sciences and the birth of new scientific disciplines. During the second half of the last century, a large number of research programmes were launched in Western Europe and the United States to investigate the spatial structures of both economy and society; new theories, instruments and institutions enriched the science and practice of social management. The rapid development of the integrative spatial

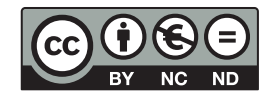


science, "regional science" occurred simultaneously with the modernisation of traditional disciplines.

The development of a regional science in Western Europe and the USA were summarised in several studies and books. The forums of regional science and the activities of its international organisations have been much discussed during the past decade. However, in these publications we find only few references to Eastern and Central European spatial research. The scarce references may be explained by the fact that the examination of the spatial evolution of the economy and society and the organisation of spatial research into an autonomous discipline were not well reflected in Eastern European research programmes. On the other hand, we may recall that neither the results achieved in determining the principles of national social and economic spaces, nor the attempts at the organisation of this science caught the attention of international professional public opinion. It is likely that both observations contain an element of truth.

The present study evaluates the regional research capacities of the countries of the former socialist block. It provides a picture of the historical antecedents of spatial research, the specifics of regional tasks to be resolved, the typical institutionalisation of regional science and its publication forums. As a conclusion, it summarises the various characteristics of regional science in the individual countries.

The positive and negative effects of processes shaping socio-economic spaces can be observed in the development of Eastern and Central Europe (CEE) in the 20th century, just as in other parts of the continent. In the policies of past eras with their heterogeneous forms of state organisation, spatial aspects were taken into consideration, too. Research results of various social-science disciplines were useful for decision makers to assess the impact of planned measures on specific regions. Such results were also incorporated in spatially-related decisionmaking processes during the late 20th century. Nevertheless, the ruling elite of the communist era requested only superficial knowledge about spatial processes. Spatial research was conducted within national borders, and international professional cooperation - with the exception of Poland and Hungary - remained weak and occasional.

Due to the introduction of the market economy after 1989 and the collapse of the Soviet Union, CEE countries were subjected to profound regional transformation. To handle these changes required a thematic and organisational development of spatial research. The preparations for EU accession provided a further impulse for research, and regional studies research groups flourished in all Central and Eastern European countries at the beginning of the $21 s t$ century. However, disparities can be observed regarding the volume, the institutional organisation and the spatial distribution of research. The multitude of factors which contributes to the identity of regional science as an autonomous discipline can be exemplified in two EU member countries, Poland and Hungary, but also in Russia. Disciplinary criteria are partly lacking or not fully developed in the remaining CEE countries. Nevertheless, significant results were achieved in the development of a European regional science, e.g. in studying the regional effects of the Eastern and Central European economic transition, the new democratic public administration, regionalisation and regional decentralisation, the system of objectives, instruments and institutions of a regional policy conforming to EU norms, the competitiveness of urban networks and cross-border cooperation.

\section{Bevezetés}

A 20. század a tudományok specializálódásának, új tudományágazatok kialakulásának korszaka volt. Az egyre bonyolultabbá váló társadalmi folyamatok, gazdasági jelenségek vizsgálatára újabb és újabb társadalomtudományi ágazatok alakultak ki. E fejlődés meghatározó mozgatórugója a tudatos társadalom- és 
gazdaságszervezés igénye volt: országot szervezni, gazdaságot müködtetni, az emberi kapcsolatokat fejleszteni ugyanis csak alapos ismeretek birtokában lehet. A modern államok gyakorlatában már viszonylag korán fontos szerephez jutottak a szociológia, a politikatudomány, a pszichológia és a közgazdaság-tudomány különböző ágazatai.

A rurális társadalomból az ipari korszakba vezető átmeneti fejlődés Nyugat-Európában az új térformáló erők felé irányította a gazdaság törvényszerüségeit feltáró korai klasszikus közgazdaságtan képviselőinek figyelmét. A kereskedelmi kapitalizmus virágkorának fiziokratái és merkantilistái a piaci terjeszkedés és a termelési költségek csökkentésében szerepet játszó térbeli összefüggésekre mutattak rá. Az ipari kapitalizmus szinte valamennyi közgazdaságtani áramlata beépítette gondolati rendszerébe a teret, a lokális, a regionális, a nemzeti és a nemzetközi dimenziókat. A területi folyamatok vizsgálatában a földrajz mint hagyományos diszciplína mellé felzárkózott a közgazdaság-tudomány is, sőt az elméletalkotásban és a területi politika alakításában a térgazdaságtan meghatározó szerephez jutott. A társadalmi-gazdasági jelenségek és folyamatok térbeli összefüggései - nem kis mértékben a társadalomtudományok módszertani fejlődése, az empirikus kutatások térhódítása és a társadalomirányítás érdeklődése nyomán - más társadalomtudományok látómezőjébe is bekerültek (Benko 1999; Egyed 2012).

A múlt század második felében Nyugat-Európában és az Amerikai Egyesült Államokban nagy számban indultak kutatási programok a társadalom és a gazdaság térszerkezetének tanulmányozására, új elméletek, eszközök és intézmények gazdagították a tudományt és a társadalomirányítás gyakorlatát. A térhez kötődő tudományos problémák kutatására és oktatására intézetek, tanszékek szerveződtek, monográfiákat, könyvsorozatokat jelentettek meg és folyóiratokat adtak ki (Isard 1975). Amilyen mértékben a térbeli megközelítés felé fordultak a közgazdászok, olyan erővel fogalmazódott meg a hagyományos regionális földrajz megújításának igénye. A diszciplináris eredmények ellenére az új gazdaságföldrajz fogalmát, kutatási metodikáját a nemzetközi tudományos közvélemény a közgazdász Paul Krugman munkásságához köti (Krugman 1991a, 1991b, 2000, 2011). A gazdaságföldrajz prominenseinek ellenvéleményét összegző tézisek cáfolják a közgazdaságtan megújítására tett kísérlet területi megalapozottságának több tételét (Czirfusz 2012; Martin 1999). A gazdaságföldrajz vezető egyéniségei is beleesnek abba a - természetesnek is tekinthető - hibába, hogy tudományágazatuk fejlödésének új útjait vizsgálva megfeledkeznek más tudományágazatok előrehaladásáról. A hagyományos diszciplínák modernizálódásával párhuzamosan ugyanis az integratív tértudomány, a „regional science” fejlődése is gyors léptekkel haladt előre. Önálló tudományágazattá válásának részleteiről még ma is viták zajlanak, a definícióról azonban letisztult álláspontra jutottak a térrel foglalkozó társadalomtudományi kutatók. Ma már közmegegyezés tapasztalható abban, hogy a regionális tudomány a térrel foglalkozó társadalomtudományok közös alapfogalmait, elméleteit és módszereit egységes rendszerbe foglaló, a társadalmi és gazdasági jelenségeket és fo- 
lyamatokat ezek felhasználásával vizsgáló tudomány (Boyce 2004; Boyce, Nijkamp, Shefer 2004; Mészáros 2006; Nemes Nagy 1998).

Az 1970-es években a fejlett ipari országok súlyos válságba jutottak: a földrajzi egyenlőtlenségek kiéleződtek, a fordista nagyipari központok hanyatlása és az új térformáló hajtóerők működése számtalan új kérdést vetett fel. A posztfordista gazdaságot alakító nagy szerkezeti változások, az új társadalomés településszerkezet kutatásában jelentős eredmények születtek az elmúlt két évtizedben. A regionális tudományi publikációk száma megsokszorozódott, a ma megjelenő több tucatnyi folyóirat felét a fellendülés szakaszában alapították. A kutatási témák spektruma is jelentősen bővült, új (például az innováció és a technológiai fejlődés, a hálózatos gazdaságok térstrukturáló hatásaival foglalkozó) irányzatok alakultak ki.

A regionális tudomány nyugat-európai és egyesült államokbeli fejlődésének eredményeit számos tanulmány és könyv összegezte (Florax, Plane 2004; Isard 2003; Isserman, 1993, 1995). Az elmúlt évtizedben is jelentek meg újabb munkák a regionális tudomány publikációs fórumairól, nemzetközi szervezeteinek tevékenységéről. Ezekben csupán néhány utalást találunk a kelet- és közép-európai területi kutatások eredményeire. A szegényes hivatkozási gyakorlatot egyrészt azzal magyarázhatjuk, hogy a gazdaság és a társadalom térbeli alakulásának vizsgálata, a területi kutatások önálló tudománnyá fejlesztése nem szerepelt a keleteurópai tudományos programokban, másrészt arra is hivatkozhatunk, hogy a nemzeti társadalmi és gazdasági terek szabályszerűségeit feltáró kutatási eredmények és tudományszervezési kísérletek nem jutottak el a széles nemzetközi szakmai közvéleményhez. Valószínű, hogy mindkét feltételezésben van igazság.

A kelet- és közép-európai regionális fejlődés vizsgálatának különleges sajátosságaként értékelhetjük azt is, hogy sok nyugat-európai kutató - például a brit Ian Hamilton (Hamilton 1974, 1982), Michael Bradshaw (Bradshaw 1993; Bradshaw, Stenning 2004) és David Turnock (Turnock 1978, 1989), a francia Marie-Claude Maurel (Maurel 1982, 2004) és Violette Rey (Rey, Gerbaud 1996) - erre a térségre, egy vagy több ország területi folyamatainak a tanulmányozására specializálódott, míg Kelet-Európában a térség folyamatait módszeresen kutató tudósok köre rendkívül szűk, összehasonlító elemzéseket a térségről lényegében csak Enyedi György végzett folyamatosan. Az ezredforduló körüli években a német Szövetségi Építési és Területfejlesztési Hivatalban a CADSES programot irányító Illés Iván tudományos munkássága szorosan e térséghez kapcsolódott (Illés 2002). Gregorz Gorzelak lengyel kutató 1996-ban publikált könyvet a transzformáció kelet-európai regionális szempontjairól (Gorzelak 1996), az ő tudományos portfóliójában a térség vizsgálata azonban nem tekinthető állandó témának. A 2000-es évek fordulóján a kelet-európai országok uniós csatlakozásának előkészületeit számos tudományos munka megjelenése kísérte, ezek azonban különböző országok kutatói által készített tanulmánygyüjtemények voltak.

E tanulmány a hagyományos szocialista blokk országainak regionális kutatási kapacitásait értékeli. Képet ad a területi kutatások történeti előzményeiről, a 
megoldandó regionális feladatok jellemzőiről, a regionális tudomány intézményesítésének sajátosságairól, a publikációs fórumokról. Végezetül összegzi a regionális tudomány különböző ismérveinek jelenlétét az egyes országokban. A területi kutatási eredmények összefoglalása, értékelése és az eredmények európai hozzáadott értékének bemutatása külön tanulmány témája lehet. E leendő vizsgálat bőven válogathat majd az utóbbi két évtized eredményeiből. A kelet- és közép-európai piacgazdasági átmenet regionális hatásai, az új, demokratikus közigazgatási térszervezés, a regionalizálás és regionális decentralizáció, az EU-konform regionális politikai cél-, eszköz- és intézményrendszer, a városhálózatok versenyképessége, a határ menti együttműködések témaköreiben az európai regionális tudomány fejlődése szempontjából is fontos eredmények születtek.

A területi kutatások helyzetéről speciális tematikával jelentek meg eddig publikációk néhány országban, a kelet- és közép-európai regionális tudományról összehasonlító elemzés azonban még nem látott napvilágot. A kelet-európai társadalomtudományok állapotát és eredményeit feltáró vizsgálat keretében a társadalomföldrajz helyzetéről készült összegzés. Ebben szép számmal találunk utalásokat a területi kutatásokra (Maurel 2002). A Nemzetközi Földrajzi Unió számára Enyedi György által készített értékelés a közép-európai alkalmazott földrajz eredményeiről szintén sok értékes információt tartalmaz (Enyedi 2003). A dolgozat módszertana szakirodalmi források értékelésén, internetes adatbázisok elemzésén és a szerző személyes tapasztalatain alapul.

\section{Regionális fejlődés és területi kutatások a 20. században}

Szinte nincs Európa évezredes történelmében olyan hosszabb periódus, amelyben a keleti térségek kiemelkedő fejlődési pályát jártak volna be. A leszakadás hosszú trendjeit csak néhány alkalommal - a középkor felívelő évszázadaiban, a felvilágosodás, majd az ipari forradalom kibontakozása idején - szakították meg a felemelkedés rövid ideig tartó szakaszai. Az általános európai fejlődési tényezők a kelet- és közép-európai településhálózat nagyvárosi elemeire voltak meghatározó hatással, a térszerkezetben itt is megjelentek a magterületek, amelyek azonban szűk kiterjedésűek voltak, a nagyvárosok közvetlen környékén kívül csak korlátozott hatást gyakoroltak a regionális fejlődésre.

\section{Regionális különbségek a birodalmak Kelet-Európájában az első világháború előtt}

A nagyrégión belüli jelentős területi különbségek kialakulásában geopolitikai körülmények is közrejátszottak. A gazdaság és a városhálózat területi szerkezetét látványosan alakító 18-19. században a térségben élő nemzetek orosz, török, porosz uralom alatt és a Habsburg Birodalom, majd az Osztrák-Magyar Monarchia 
keretei között éltek. A politikai függésből adódóan az önálló fejlődési lehetőségek meglehetősen korlátozottak voltak. A nagytérségen belüli területi fejlődés elsősorban annak a következménye volt, hogy a birodalmi központok milyen gazdaságpolitikát folytattak. Ezek a különbségek leglátványosabban a cári Oroszországhoz és Poroszországhoz tartozó szomszédos lengyel térségek gazdasági teljesítményeinek alakulásában mutathatók ki.

A nemzeti mozgalmak intézményesülése közvetett módon a majdani nemzetállamok területi fejlődésére is hatással volt. Különösen az orosz érdekszférához tartozó nemzetek fogalmaztak meg határozott álláspontot a birodalmi nemzetiségi politika elnyomó intézkedéseivel szemben. Az orosz államhatalom a perifériák közigazgatásának működtetésében területi-nemzeti sajátosságokat is felhasznált. A cári fókormányzóságok - néhány kivételtől eltekintve - multietnikus képződmények voltak. A régiók történelmi, etnikai és földrajzi viszonyaira is tekintettel voltak akkor, amikor a birodalmi akarat érvényesítésének különböző formáit kialakították (Lieven 2000).

A 19. század végén a cári Oroszországban az ipari termelés 92 százalékát az európai országrészek adták. E területeken a koncentráció mértéke folyamatosan nőtt. A század utolsó évtizedében a birodalom legfejlettebb ipari térségei a Moszkvai, a Varsói, a Vlagyimiri és Szentpétervári kormányzóságok voltak. Ezekben az ezer lakosra jutó ipari foglalkoztatottak száma 32-82 között mozgott, a legfejletlenebb térségekben 1-7 fő között alakult. Az 1900-as évek első évtizedében a nagyrégiók ipari termelési adatai 10-12-szeres különbséget mutattak. Az egy före jutó gyáripari termelési érték a 20. század legelején Oroszországban 31 rubel volt, az északnyugati régiókban és a Baltikumban ez az érték 87 rubelt, a Közép-oroszországi ipari körzetben 78 rubelt, az ázsiai Oroszországban pedig 8 rubelt tett ki (Horváth 2008). Az ország természeti erőforrásainak hasznosítása rendkívül alacsony színvonalú volt, a birodalom területének 90 százalékán ismeretlenek voltak az erőforrások.

A cári Oroszország területi expanziójának és a modern gazdaság térbeli szerveződésének megalapozásához az orosz földrajz-, közgazdaság- és agrártudomány jeles képviselői járultak hozzá. A kitűnő geográfus-statisztikus, Pjotr P. Szemjonov-Tjan-Sanszkij 1800-as évek utolsó harmadában megjelent négykötetes összegző munkája, Az Orosz Birodalom földrajzi statisztikai szótára az államhatalmi szervek regionalizációs és közigazgatási feladataihoz nyújtott támpontokat. Az orosz agrárpiacok regionális szervezéséhez, a mezőgazdaság és a falvak fejlesztéséhez járultak hozzá az agrárközgazdász Alekszandr Ny. Cselincev és Alekszandr I. Szkvorcov kutatásai.

Magyarország modernizációs programjai, a vasútépítkezések, a vízügyi munkálatok és az állami finanszírozású - elsősorban budapesti - közmunkák jelentős változásokat indítottak el az ország térszerkezetében a 19. század végén. Ezek döntő részben koncentrációs jellegüek voltak, a főváros országon belüli és nemzetközi pozícióit erősítették. Az akkori kormányzatok ugyan nem dolgoztak ki mai értelemben vett területfejlesztési politikát, azonban az elmaradott or- 
szágrészekben kibontakozó modernizációs követelésekre válaszokat kellett megfogalmazniuk. A perifériák eltérő erősségű akcióit az Országos Magyar Gazdasági Egyesület (OMGE) karolta fel, az egyesület müködési filozófiájában ugyanis fontos szerepet kapott a területi különbségek mérséklése. Az első kormányzati fejlesztési program az Északkelet-Kárpátokban indult az 1890-es évek végén, majd az 1902. évi Székely Kongresszus határozatai nyomán fogalmazódott meg kormányzati felzárkóztatási stratégia az ország egyik legelmaradottabb térsége, a Székelyföld modernizálására. A Székely Kongresszust - amely a térség szereplőinek fejlesztési törekvéseit példamutató módon foglalta egységes rendszerbe - a magyar területfejlesztési tradíció fontos elemének kell tekintenünk (Székely Kongresszus 2001). A történelem vihara ugyan megakadályozta, hogy az ajánlásokat konkrét kormányzati és helyi cselekvés kövesse, a kongresszus jegyzőkönyve területfejlesztési szakembereknek érdekes és elgondolkodtató olvasmány lehet ma is.

\section{A régiók nemzetállammá integrálódása a két világháború között}

Az első világháború után megalakult új kelet- és közép-európai államok első kormányainak nemcsak a gazdasági teljesítőképességben megmutatkozó területi különbségeket kellett érzékelniük, hanem a társadalmi, politikai és közigazgatási intézményrendszerben tapasztalható eltéréseket is. E gondok valamennyi új államban igen tetemesek voltak, hiszen az új országok tartományai korábban különböző birodalmakhoz tartoztak. A politikai-hatalmi uniformizálás jelentős tőkét emésztett fel. Az egységes államszervezet megteremtésében a területi különbségek mérséklésének igénye nem szerepelt az elsődleges állami feladatok között. Több országban azonban a közlekedési hálózat egységesítése, az energiatermelés bővítése, a többségi nemzet társadalmi-politikai intézményeinek kiépítése során megfogalmazódtak területpolitikai feladatok is. A két legnagyobb ország, Lengyelország és a Szovjetunió foganatosította a legtöbb intézkedést, hogy az ország regionális berendezkedésének gazdasági alapjait megteremtse.

Az egységes Lengyelország 1918. évi kikiáltását követően a legelső feladatok egyike a felső-sziléziai szénmedence és a Balti-tenger közötti szállítási útvonalak kiépítése volt. A katowicei iparvidékről kiinduló vasútvonalat meg kellett építeni a tengerig, valamint a német fennhatóság alatt maradt Gdańskot (Danzigot) helyettesítendő új kikötői beruházásokat és városfejlesztési programot kellett indítani Gdyniában. Ezek a célkitűzések 1926-ra teljesültek. A gazdaság alapjainak bővítése az ipar fejlesztését igényelte az 1930-as évek közepén még 66 százalékos agrárfoglalkoztatottságot mutató országban. Több térség került a politikai cselekvés homlokterébe. Tizenkét fejlődési nehézségekkel küszködő térséget határoltak le. Ezek egy csoportját a német határmegvonások sújtották és politikailag érzékeny területek (az ún. „lengyel folyosó” Németország és Danzig szabad város között) alkották, egy másikba a túlnépesedett, paraszti gazda- 
ságok által dominált vagy hegyvidéki jellegük miatt kevéssé fejlődőképes régiók (Białystok, Lwów, Kielce régiója, Dél-Lengyelország) kerültek. Külön csoportot képviseltek a történelmi iparvidékek (Łódż, Poznań, Felső-Szilézia). S végül Varsó fơvárosi funkcióinak teljesítéséhez az elmaradott agrárrégió teljes infrastrukturális megújulására volt szükség (Hamilton 1982).

A problematikus térségek fejlődési nehézségei természetesen a második világháború után is fennmaradtak, sőt egy részükre a mai napig sem találtak teljes körű megoldást, a programoknak azonban számos kedvező következménye volt. Mindenekelőtt tudatosult a területi szempontok fontos szerepe a nemzetgazdasági tervezésben. E felismerés eredményeképpen módszeres adatgyüjtés kezdödött, népesedési és gazdasági prognózisokat állítottak össze, a háború utáni tervezési rendszer területi alapjai már ekkor létrejöttek (Malisz 1978). A Lengyel Várostervezők Társasága 1932. évi konferenciája fogalmazta meg először a területi tervezés alkalmazásának szükségességét, 1936-ban megalakult a Varsói Regionális Tervezési Társaság. A társaság adta ki Lengyelország statisztikai atlaszát, amelyben az országot két részre tagolták. „A” Lengyelországot a Visztulától nyugatra elhelyezkedo, fejlett területek, „B” Lengyelországot pedig a keleti régiók alkották. A társaság arról igyekezett a kormányt meggyőzni, hogy utóbbi térségek az 1936-1940 közötti állami beruházási terv fó kedvezményezettjei legyenek. Az előbbiekben említett speciális térségekben a lengyel belügyminisztérium tervezési hivatalokat létesített. A Krakkó, Sandomierz és Lwów közötti elmaradott térséget a honvédelmi tárca irányítása alá vonták, a Németországhoz közeli Felső-Szilézia helyett ezt a területet jelölték ki a lengyel hadiipar fejlesztési övezetének.

Az elmaradott perifériák fejlesztését a Szovjetunióban az állami ideológia rangjára emelték, a falu és a város közti különbségek felszámolásának illuzórikus programjai mögött lényegében az a gazdaság- és területpolitikai gyakorlat húzódott meg, hogy a tagköztársaságok erőforrásait a birodalom katonai-védelmi és hatalmi érdekeinek rendeljék alá. A szovjethatalom első évtizedének néhány fejlesztési kísérlete ugyanakkor felhívta a nemzetközi szakmai közvélemény figyelmét. A komplex területi gazdaságfejlesztési stratégiák előképének tekinthetjük az ország átfogó villamosítási koncepcióját, az ún. Goelro-tervet. Ebben a tervben fogalmazódott meg a nagyrégiók kialakításának az igénye. 21 gazdasági körzetet alakítottak ki az energetikai és általában a gazdaságfejlesztési programok kidolgozására és megvalósításuk szervezésére (Tarhov 2005). Az iparosítási koncepció az Uráltól nyugatra elterülő országrészre helyezte a hangsúlyt. Az ipari beruházások több mint fele a régi ipari térségek közelébe - a Volga mentére, a Kuznyecki-medencébe - települt. A nyersanyag-lelőhelyek közelében védelmi szempontból és nem a területi fejlődés érdekében létrehozott új ipartelepek az ipari potenciál keletre tolódását segítették elő, ennek köszönhető Szibéria több régiójának gyors betelepítése. A nagymértékü regionális különbségek az országban fennmaradtak, sőt a modern térformáló erők esetében folyamatosan növekedtek. 
A második világháború idején jelentős területi átrendeződés zajlott le az iparban. Az Urálba és a Volga vidékére került a kitelepített vállalatok közel kétharmada, Nyugat-Szibériába 16 százaléka (Trejvis 2002). 1941-ben a moszkvai vállalatok nagy részét a várostól keletre fekvő területekre és Szibériába evakuálták. Az európai ipari térségek termelése ennek következtében a felére esett vissza. Szibéria súlya a termelési érték adatai szerint még kevésbé volt jelentős, a foglalkoztatottak száma alapján azonban jelentős pozíciónövekedés volt tapasztalható. A második világháború után a nyugati területek fejlődése gyorsult fel. Az 1940-es évek végétől indultak a keleti térségekben azok a kőolaj-, gáz- és más nyersanyagipari fejlesztések, amelyek az 1930-as évek geológiai kutatásain és a természeti erőforrások feltárásán alapultak. A keleti régiók (Kazahsztán, Szibéria és a Távol-Kelet) jelentősen megerősítették nyersanyagtermelésben elfoglalt pozícióikat.

A népgazdasági tervek regionális programjainak tudományos előkészítését az 1920-as években a tudományos akadémia Természeti Termelőerők Kutatásának Bizottsága (Komiszszija po izucsenyiju esztesztvennüh proizvoditel'nüh szil - KEPSz) végezte. A szervezetet a cári orosz akadémia alapította 1915-ben. Az intézmény gondozta a Goelro-terv regionális alprogramjait is. 1930-ban a szervezetet átalakították, Termelőerők Kutatásának Tanácsa (Szovjet po izucsenyiju prozvoditle'nüh szil - SzOPSz) néven az állami tervhivatal intézménye lett (Adamesku 2012).

Az országrészek egységes állammá szervezésének regionális következményei Kelet-Közép-Európa többi új államában is értékelhetőek voltak. Például a magyar gazdaságpolitika stratégiai célja a harmadára zsugorodott ország belső kohéziójának megteremtése, az ipari kapacitásoknak az új piaci területekhez való igazítása volt. Az új Romániában a területi különbségek nagy méreteket öltöttek. Erdély urbanizációs színvonala (városhálózatának sűrűsége), iparosodottsága jócskán meghaladta az óromániai régiókét. Az erdélyi országrész az új Románia lakosságának 30 százalékát adta, miközben az ipari kapacitásokból 4050 százalékos súllyal részesedett. Csehszlovákiában a cseh ipar új szlovákiai piacainak a kialakítása és a közlekedési infrastruktúra összehangolása határozta meg a Felvidék betagolódását az új nemzeti gazdasági térségbe. A politikai kohézió megteremtéséhez szükséges formális hatalmi-közigazgatási szerkezetnek is voltak közvetlen és közvetett hatásai a városhálózat fejlődésére, egyes városi térségek gazdasági potenciáljának az alakulására.

A két világháború közötti rövid időszak térfelosztáshoz kapcsolódó államszervezési és társadalompolitikai feladatai több tudományágazatban hangsúlyossá tették a térbeli gazdasági folyamatok, a területi közigazgatási szervezetrendszer és irányítási modellek, a településrendszer és a népességi átrendeződés vizsgálatát. Ebben a korszakban sok elismert társadalomkutató tudományos tevékenységének voltak érzékelhető következményei az állam müködésében. $\mathrm{E}$ helyütt a román Dimitrie Gusti faluszociológiai munkáit, a magyar Rónai András államtudományi vizsgálatait, a cseh Viktor Dvorský gazdaság- és társadalom-földrajzi elemzéseit 
említjük. Az alkalmazásban hagyományosan élenjáró orosz (majd szovjet) gazdaságföldrajz nagy egyéniségei, Ivan G. Alekszandrov, Nyikolaj N. Baranszkij, Nyikolaj N. Koloszovszkij a gazdasági körzetesítésben, a területi tervezés megalapozásában hasznosították kutatási eredményeiket.

A második világháború idején Közép-Európa több pontján jöttek létre új intézetek, amelyek a régiók adottságainak feltárását tekintették feladatuknak a háborút követő újjáépítés tudományos megalapozásában. Lengyelországban a toruní Balti Intézetet, a wroclawi Szilézia Intézetet, a poznańi Nyugat Intézetet, Morvaországban az opavai Szilézia Intézetet és Magyarországon a pécsi Dunántúli Tudományos Intézetet lehet említeni. Az intézetek közül ma kettő működik. A poznańi intézet mai profilja a lengyel-német kapcsolatok kutatása. Az 1943ban alapított pécsi intézet 1971-ben a magyar területfejlesztési alapkutatások bázisa lett, majd 1984-ben az MTA Regionális Kutatások Központjának székhelyeként folytatta tevékenységét.

\section{Az államszocializmus területpolitikája}

A szocialista tervgazdaságok a területi egyenlőtlenségek mérséklését elsődlegesen az iparfejlesztési programok megvalósításával kívánták elérni. Az iparosítással párosuló infrastrukturális fejlesztések és az urbanizáció felgyorsulása a nagyrégiók közötti jövedelmi különbségek csökkenését eredményezte.

A tervgazdálkodás rendszerében a területi tervezés fontos helyet foglalt el: Lengyelországban 1961-ben fogadtak el törvényt a területi tervezésről. A hosszú távú területi tervek foglalták magukban a regionális fejlesztési stratégiák alapelemeit, több országban (Bulgária, Magyarország, Románia) településhálózat-fejlesztési koncepciók készültek.

Az államszocializmus regionális és településpolitikájának ideológiája (a klasszikus marxi elmélet, az utópisztikus urbanisztikai elképzelések, a tervezéselmélet) és az ebből fakadó célkitűzések (az arányos fejlesztés, a falu és a város közötti civilizációs különbségek mérséklése, az ingyenes vagy a jelentősen támogatott társadalmi juttatások térben egyenletes elosztása) erős korlátok közé szorították a területi folyamatok tanulmányozásával foglalkozó tudományágazatokat. A homogénnek feltételezett társadalom eszménye azonban a tudományos gondolkodást differenciáltan hódította meg az egyes országokban. A lengyel és a magyar társadalomtudományok viszonylag korán, már a hatvanas évtizedtől kezdődően - jórészt a nyugati tudományossággal fenntartott intenzív kapcsolataik következtében - fontos kutatási eredményeket szolgáltattak a térben egyenlőtlen fejlődésről, a településhálózat átalakulásának anomáliáiról, és „expressis verbis” megkérdőjelezték a központi tervgazdálkodás, a helyi-regionális adottságokkal nem számoló gazdaságpolitika hatékonyságát (Domański 1973; Dziewoński 1967; Enyedi 1981).

A tervgazdaságok térszerkezeti átalakulását elemző vizsgálatok eredményei arra hívták fel a figyelmet, hogy a Kelet-Közép-Európában kialakult gazda- 
sági szerkezet és urbanizációs típus nem önálló modell, hanem a nyugat-európaihoz hasonló urbanizációs és fejlődési szakaszok követték egymást jelentős késéssel. A területi fejlődésben megmutatkozó különbségek egyrészt a megkésettséggel, másrészt az államszocialista rendszer müködésével magyarázhatók (Enyedi 1989).

A kelet- és közép-európai tudomány sajátos fejlődési útjai miatt a társadalmi és gazdasági tér kutatásának is számos különös vonása fedezhető fel. A szocialista tudománypolitika a hatalmi berendezkedés irányelveit követve a tér kutatását nem tekintette kiemelt feladatnak. Ennek oka alapvetően az volt, hogy a helyi-regionális sajátosságok feltárásában a szigorú szabályok szerint központosított államszervezet egyik szintje sem volt érdekelt. A homogenizálni szándékozó politikai gyakorlat csak annyi figyelmet fordított a területi szempontokra, amennyit a tervezés igényelt.

Az 1948-1990 közötti korszak az egyes tudományágazatoknak a társadalmigazdasági tér kutatásával kapcsolatos feladatokat kínált, a megrendelői igények azonban sem komplexek nem voltak, sem pedig a társadalomirányítás szempontjából nem igényelték a tudományágazatok tematikai együttműködését. A térbeli viszonyokkal foglalkozó hagyományos tudományágazatok (gazdaságföldrajz, település- és közigazgatás-tudomány, bizonyos esetekben a közgazdaság-tudomány) mind az akadémiai, mind pedig az egyetemi szférában folytathatták működésüket. A területfejlesztés tudományos megalapozása elsődlegesen állami intézményekben, az országos tervhivatalokban, urbanisztikai tervezőintézetekben folyt.

A kelet-európai társadalomtudományok differenciálódásában is kimutatható a területi folyamatok vizsgálatából levont következtetések dinamizáló hatása. A szociológia önálló diszciplínává válásában - elméleti és módszertani szempontból egyaránt - fontos felhajtóerőt jelentettek a társadalom szerkezetének települési különbségeit feltáró kutatási eredmények, a politológia legitimálásában pedig a közigazgatási-hatalmi viszonyok területi-települési komponenseinek vizsgálatai (Bihari 1983; Kulcsár 1986; Musil 1977).

A területi kutatásokat két országban koordinálták intézményesen. A Szovjetunóban továbbra is működött a Termelőerők Kutatásának Tanácsa, Lengyelországban pedig a Lengyel Tudományos Akadémia 1958-ban alakította meg a Térgazdaságtani és Területi Tervezési Bizottságot (Kukliński 1966). E két intézmény általános koordinációs jogosítványainak gyakorlásához külön finanszírozási forrásokkal rendelkezett. A harmadik országban, Magyarországon az országos területfejlesztési koncepcióról megjelent kormányhatározat 1971-ben a területfejlesztési alapkutatások szervezését a Magyar Tudományos Akadémia feladatává tette, ami országos hatókörü kutatási koordinációt nem jelentett.

A szocialista országok területi kutatóinak együttműködése az 1970-es évek közepétől vált rendszeressé. A tervhivatalok szervezésében zajló konferenciák előadásainak publikálására a moszkvai Progressz Kiadó A szocializmus és a kommunizmus épitésének kérdései című sorozatában vállalkozott, azonban mindössze két kötet jelent meg. 
A területi folyamatok vizsgálatának vezető tudományágazata a társadalomés gazdaságföldrajz volt. Valamennyi tudományos akadémiának volt földrajzi kutatóintézete, az ezekben folytatott alkalmazott földrajzi kutatások eredményei befolyásolták a korszak területfejlesztési döntéseit. Az intézményi innovációban ugyancsak Lengyelország járt az élen, az 1970-es évek elején a Lengyel Tudományos Akadémia földrajzi intézetének nevét Földrajzi és Térgazdasági Intézetre változtatták. Magyarországon 1984-ben az MTA területi alapkutatásokat végző Dunántúli Tudományos Intézetének bázisán létrejött a hálózatos formában müködő Regionális Kutatások Központja. A kutatóközpont a Pécsi Tudományegyetem Közgazdaságtudományi Karával közösen 1988-ban területfejlesztési posztgraduális képzést indított. Az egyetemi földrajztudományi tanszékek és intézetek tudományos kapacitásai is jelentősek voltak, bár a szocialista felsőoktatásban e diszciplína a tanárképzést szolgálta. Több országban a müszaki egyetemek urbanisztikai tanszékei elismert kutatási műhelyekként szerepeltek.

A lengyel és a magyar területi kutatások folyamatos fejlődését elősegítő körülmények között meg kell említeni a két ország politikai rendszerében tapasztalható reformszellemiséget is. Ennek köszönhetően a két ország tudományos műhelyeinek kapcsolatai a nyugat-európai kutatóhelyekkel fennmaradtak, közös kutatások is voltak, az országos, regionális és helyi politikai elitek érdeklődést mutattak a kutatási eredmények iránt. Nem járunk messze az igazságtól, ha azt állítjuk, hogy a regionális kutatások aktív szerepet játszottak a rendszerváltozás előkészítésében (Maurel 2002). A kutatások eredményei határozottan arra hívták fel a figyelmet, hogy a gazdaság megújítása a térszerkezet jelentős átalakítását igényli, újra kell fogalmazni a területfejlesztési politika céljait, elveit és intézményeit. A központi állam, a helyi-területi közösségek, a közösségi és a magánszféra együttműködése, fejlesztési koalíciója lehet az új társadalomirányítási modell kiindulópontja.

\section{Regionális átalakulás a rendszerváltozás után}

1990-ben új folyamatok indultak el a kelet- és közép-európai területi fejlődésben. Hatásai legalább olyan drámaiak voltak, mint amilyen változásokat az erőltetett iparosítás előidézett. A piacgazdaságra való áttérés időszakában a demográfiai, munkaerő-piaci, gazdasági és környezeti folyamatok jelentős eltéréseket mutattak Kelet-Közép-Európában. A nyugat-európai szakértők előszeretettel kezelik e térséget homogén egységként, az államszocializmus öröksége, még inkább a transzformáció regionális hatásai és az új jelenségek menedzselésében alkalmazott gazdaságpolitikai eszközök, intézményi megoldások azonban igen eltérő eredményre vezettek. A gazdaság szerkezetének radikális átalakulása az egyes régiókat eltérően érintette. Az átalakulás vesztesei - más európai országokhoz hasonlóan - a nehéz- és a kitermelő ipari térségek és - kelet-európai jellegzetességként - az összefüggő agrárvidékek lettek. A piacgazdaság kiépülése 
a regionális különbségek fokozódását idézte elő. A nagy különbségek abban is kifejezésre jutnak, hogy - Bulgária kivételével - mindenütt vannak kiemelkedöen fejlett régiók. A tíz leggazdagabb kelet-közép-európai régió négy országban található: hat Csehországban, kettő Magyarországon, egy-egy Szlovákiában és Romániában. A tíz legszegényebb régió viszont a két később csatlakozott országban, Bulgáriában és Romániában helyezkedik el (Horváth 2004). A nyers piaci hatások átütő érvényesülésének Oroszország a mintapéldája. Álljon itt két adat a regionális problémák illusztrálására: 1 . A legnagyobb és a legkisebb jövedelmű régió között negyvennégyszeres a különbség, 2. Moszkva részesedése az ország GDP-volumenéből az 1994. évi 10,3 százalékról 2007-re 23,8 százalékra emelkedett. Eközben Szentpétervár súlya 3,3 százalékról csupán 3,9 százalékra nőtt (Dergacsev, Vardomszkij 2010).

A rendszerváltás utáni legelső demokratikus kormányzatok tevékenységének egyik jellemző hiányossága volt Kelet-Közép-Európában, hogy kevés figyelmet fordítottak a gazdaság szemmel láthatóan drámai területi átrendeződésére. Csupán Magyarország számított kivételnek, ahol az 1990. évi demokratikus választások után a kormányzati struktúrában Környezetvédelmi és Területfejlesztési Minisztériumot hoztak létre, és kormányprogramok készültek az akut válsággal küszködő nehézipari térségek szerkezetátalakítására. Az egész országra érvényes, koherens regionális politikai stratégiája egyetlen kormánynak sem volt, mint ahogy a korábbi területfejlesztési programokat sem alakították át az új fejlesztési céloknak megfelelően, hanem inkább megszüntették azokat. A politikai elit nem értette meg a területfejlesztés lényegét, nem kevesen voltak, akik ezt a tevékenységet a tervgazdaság hajdan volt eszközével azonosították, és a népgazdasági tervezés maradványának tekintették. Ez a politikai légkör az 1990-es években nem kedvezett a területi kutatások tematikai és intézményi megújulásának.

A regionális politika az új uniós tagországokban számtalan gonddal találta magát szemben. A területfejlesztési törvények által létrehozott intézmények működését az instabilitás jellemezte. Kormányzati ciklusonként változik a regionális politika központi intézménye is: Magyarországon ez idáig nyolc alkalommal került más-más hatósághoz a területfejlesztés irányítása. Az európai uniós struktúrapolitikai alapelvek érvényesítése számos nehézségbe ütközik: nem alakult ki a decentralizált döntési mechanizmusok hatékony müködését megteremtő intézményrendszer, az államháztartási reform késlekedése miatt az addicionalitás szempontjai nehézkesen érvényesíthetőek, a programfinanszírozás a területfejlesztési szereplők gyenge együttműködési készsége miatt alacsony hatásfokkal müködik, és még hosszasan sorolhatnánk a várakozásokkal ellentétes területpolitikai gondokat. Mindezek egyenes következménye, hogy a területi különbségek valamennyi országban továbbra is folyamatosan nőnek, eltérések csupán azok mértékében tapasztalhatók.

Az európai uniós tagság, az intézményi változások és a bővülő pénzügyi lehetőségek a területi kutatások szempontjából is kedvező feltételeket teremtet- 
tek. Az uniós strukturális politika alkalmazásához, a regionális fejlesztési programok és koncepciók kidolgozásához új ismeretekre volt szükség egyrészt a nyugat-európai fejlesztéspolitikai gyakorlatról, másrészt a nemzeti fejlesztési tervekben megjelenő régiók gazdasági és humánerőforrás-potenciáljáról. Az új igények tudományos keresletet generáltak, több országban a szakemberképzésben is megjelentek a regionális fejlesztési szempontok. A volt Szovjetunió legnagyobb utódállamában, a föderatív berendezkedésű Oroszországban a regionális tudományi ismeretek a régióközi kapcsolatok újjászervezése és a regionális igazgatási jogosítványok bővülése miatt váltak fontossá.

\section{Területi kutatások a 21. század elején}

\section{Intézményi keretek}

A rendszerváltozást követően a térbeli folyamatok ismeretének igénye jelentősen bővült. A területi kutatások intézményi szerkezetében is fontos változások következtek be. Több országban az akadémiai kutatóintézetek nehéz anyagi helyzetbe kerültek, a cseh földrajzi intézetet felszámolták, Bulgáriában földtudományi kutatóközpontot hoztak létre, amelyben a társadalomföldrajznak rendkívül szerény lehetőségei vannak. Magyarországon szintén intézeti összevonások voltak, a Regionális Kutatások Központja elveszítette irányítási jogosítványait, az országos hálózat meggyengült. Az új kutatóközpont tényleges székhelye Budapesten van, a decentralizált tudományirányításban felhalmozott kedvező tapasztalatok vélhetően veszendőbe mennek. A szocialista korszak terület- és településfejlesztési feladatainak kidolgozásában és megvalósításában jelentős szerepet vállaló, nagy intellektuális kapacitásokkal rendelkező állami várostervező intézetek megszüntek.

Az egyetemi regionális kutatási kapacitások súlya ugyanakkor megnőtt. A kutatás újra az egyetemek fö tevékenységei közé került, a képzés szerkezete is átalakult. A földrajzi képzésben megjelentek az alkalmazott geográfus szakok, amelyeken terület- és településfejlesztési szakemberek oktatása is folyik. A közgazdaság-tudományi képzés teljes megújításának egyik eredménye a területi gazdaságtani és regionális politikai képzés megszervezése volt.

Internetes adatgyüjtésen alapuló számításaim szerint ma Kelet-Közép-Európa vizsgált hat országában kutatóintézeti és egyetemi mühelyekben több mint 900 fö foglalkozik területi kutatásokkal. A kutatói létszám megoszlása országok között és országokon belül is nagy különbségeket mutat (1. táblázat, 1. ábra).

A részletesebben vizsgált országok közül a regionális tudományi kutatások és képzés legjelentősebb potenciálja Lengyelországban található. Poznań, Łódż, Varsó, Krakkó és Wrocław a legtekintélyesebb regionális tudományi kutatási 
1. táblázat: A regionális kutatók száma a kelet-közép-európai országokban, 2012

The number of regional science researchers in Eastern and Central European countries, 2012

\begin{tabular}{lccc}
\hline \multicolumn{1}{c}{ Ország } & $\begin{array}{c}\text { A tudományos kutatók } \\
\text { száma, fó }\end{array}$ & Megoszlás, százalék & $\begin{array}{c}\text { A fóvárosi kutatóhelyeken } \\
\text { foglalkoztatottak aránya, } \\
\text { százalék }\end{array}$ \\
\hline Bulgária & 30 & 3,2 & 100,0 \\
Csehország & 115 & 12,2 & 34,8 \\
Lengyelország & 425 & 45,2 & 17,5 \\
Magyarország & 150 & 16,0 & 20,0 \\
Románia & 130 & 13,8 & 31,9 \\
Szlovákia & 90 & 9,6 & 33,3 \\
Összesen & 940 & 100,0 & 20,1 \\
\hline
\end{tabular}

Forrás: Internetes adatgyüjtés alapján a szerző becslése. A táblázat azokat az egyetemi és kutatóintézeti mühelyeket tartalmazza, amelyek elnevezéséból, kutatási programjából és publikációiból a regionális tudományi tematika megállapitható.

1. ábra: A területi kutatások mühelyei Kelet-Közép-Európában, 2012

Spatial research workshops in Eastern and Central Europe, 2012

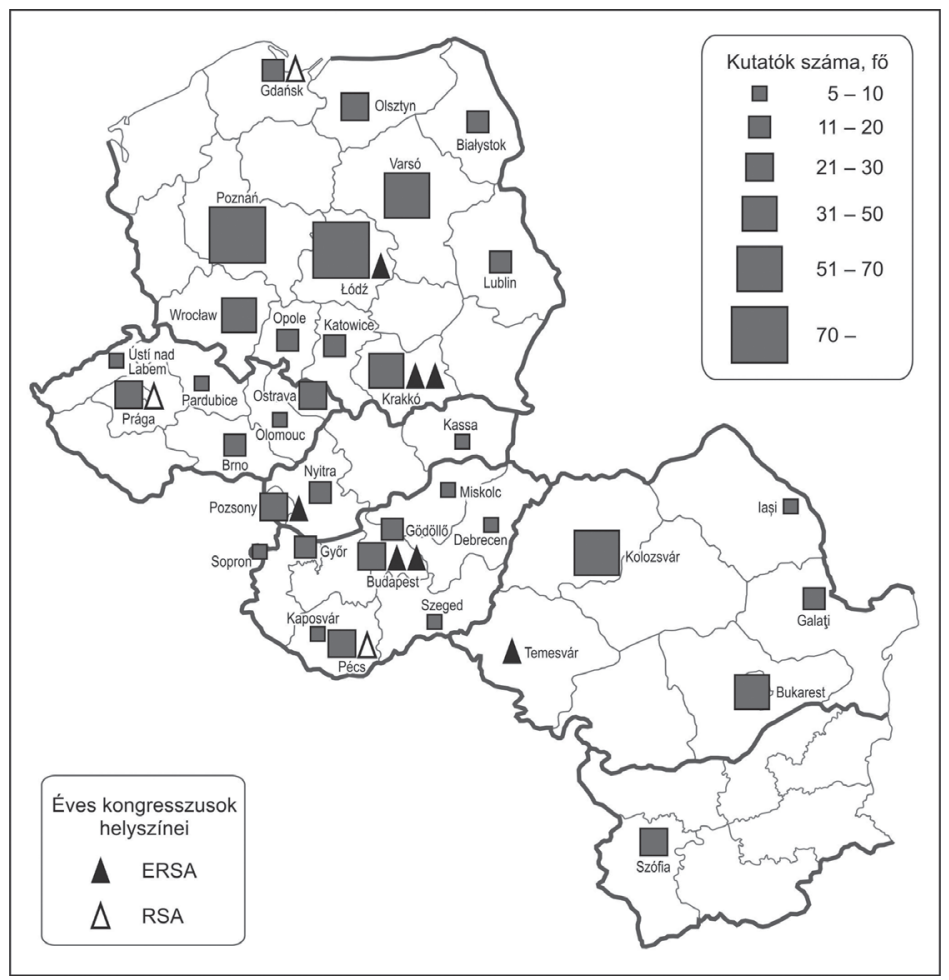

Forrás: A szerző szerkesztése internetes adatforrások felhasználásával. 
központ az országban. Magyarország a lista második tagja (a legfontosabb mühelyközpont Pécs és Budapest), a kutatóhelyek területi elhelyezkedése is egyenletesebb, mint az azt követő Romániában, ahol mindössze négy városban találunk regionális tudományi műhelyt. Csehországban is a három legnagyobb város tekinthető a regionális kutatások központjának. Szlovákia a regionális tudomány szempontjából hárompólusú, Bulgáriában pedig mindössze a főváros akadémiai és egyetemi földrajztudományi intézeteiben lehetett nyomára bukkanni a regionális tudomány művelésének. Kelet-Európa 30 városában kb. 60, regionális kutatásokkal főhivatásszerűen foglalkozó tudományos műhelyt regisztrálhatunk a 2010-es évek legelején. E műhelyek mindegyikének több évre szóló kutatási programja van, eredményeiket rendszeresen közzéteszik, munkatársaik gyakori szereplői nemzetközi tudományos fórumoknak, publikálnak és konferenciákon vesznek részt.

Nem tekinthetünk el attól, hogy ne szóljunk az orosz regionális tudomány intézményi hátterének néhány vonásáról. Ennek az országnak a feldolgozásához a jelenlegi tanulmány keretei szüknek bizonyultak, a tekintélyes tudományos információtömeg összegyűjtése és feldolgozása hosszabb időt vesz igénybe. Az orosz regionális kutatások évszázados hagyományokkal rendelkező vezető intézményei - mint láttuk - működnek, a „regional'naja nauka” elismert tudományos diszciplína Oroszországban. A tudományágazatnak az országban két meghatározó szellemi centruma van: Moszkva és Novoszibirszk. Az orosz fővárosban akadémiai és szövetségi ágazati kutatóintézetek tucatjainak kutatási tervében találunk regionális tudományi témákat. Két intézmény érdemel különös figyelmet. Az Oroszországi Tudományos Akadémia Földrajztudományi Intézetének számos munkatársa publikál rendszeresen figyelemfelkeltő munkákat nyugati tudományos kiadóknál (Artobolevsky 1997; Ioffe, Nefedova 2000; Lappo, Hönsch 2000). A másik fontos műhely a már említett Termelőerők Kutatásának Tanácsa, amely kutatási programokkal, könyvkiadással és folyóirat megjelentetésével látja el koordinációs feladatait. A novoszibirszki tudományos centrum az orosz akadémia szibériai tagozatának Közgazdasági és Ipari Termelésszervezési Intézete. A szovjet peresztrojka egyik reformintézete három tudományos iskolával büszkélkedhet a regionális tudományban. Az egyik Szibéria területfejlesztési stratégiáinak tudományos megalapozásához és a területi tervezés továbbfejlesztéséhez kötődik, a másik az orosz településszociológia vezető mühelye, a harmadik pedig a matematikai-statisztikai elemzési módszerek és modellezés legjobb orosz tradíciói alapján működő tudományos közösség. A két moszkvai és a novoszibirszki intézet alkotja az orosz akadémia által koordinált, Az Oroszországi Föderáció területi fejlődésének interdiszcplináris szintézise című szövetségi kutatási program tudományos bázisát (Kotljakov, Glezer, Trejvis, Svecov 2012; Kulesov, Szeliversztov, Suslov, Suspicyn 2012).

A kutatóhelyeken kívül a területi kutatások fontos intézményei a tudományos társaságok. A tudományos társaság a tudományágazat kutatóin kívül a tudományos eredmények alkalmazásában érdekelt gyakorlati szakembereket, a 
regionális fejlődés iránt érdeklődő értelmiségieket tömöríti. Ezek az értelmiségi szerveződések önálló intézményekként vagy a nemzetközi regionális tudományi társaságok nemzeti tagozataként működnek. Az első csoportba a magyar és a román regionális tudományi társaság tartozik. A Román Regionális Tudományi Társaság 2000-ben alakult, jelenleg 140 tagja van. Éves tematikus konferenciáin a román területi kutatási eredményeket ismerteti, Romanian Journal of Regional Science címmel folyóiratot jelentet meg évente két számmal. A Magyar Regionális Tudományi Társaság 2002-ban alakult, ma 430 tagot számlál. Éves közgyűléseihez tematikus konferenciák kapcsolódnak. A többi országban a regionális kutatók szerveződései a European Regional Science Association vagy a Regional Studies Association nemzeti tagozataiként jelennek meg. Lengyelországban a Lengyel Tudományos Akadémia Területi Gazdasági Bizottsága (Komitet Przestrzennego Zagospodarowania Kraju PAN) tekinthető a regionális tudományi kutatások integrációs központjának. A hat munkacsoportot müködtető bizottság három kiadványsorozatot jelentet meg. A Magyar Tudományos Akadémia 1986-ban alapított Regionális Tudományi Bizottságának 115 tagja öt munkabizottságban végzi a munkáját.

\section{Publikációs fórumok}

A területi kutatási eredmények publikálása - a nemzetközi gyakorlatnak megfelelően - a 20. század első felében Kelet-Európában is más szaktudományi folyóiratokban volt lehetséges. Földrajz- és gazdaságtudományi, szociológiai és közigazgatástudományi orgánumok jelentették meg a területi folyamatok vizsgálatának eredményeit. A lengyel akadémiai bizottság kiadványsorozatain, a novoszibirszki akadémiai közgazdasági intézet folyóiratán, továbbá a magyar Területi Statisztika címü folyóiraton kívül az 1980-as évtized közepéig egyetlen országban sem voltak a regionális tudománynak saját publikációs fórumai. A rendszerváltozás előtt a magyar Tér és Társadalom 1987. évi megjelenése tudományos újdonságnak számított, és nagy érdeklődés kísérte nemzetközi szakmai körökben is.

A folyóirat-alapítások meghatározó időszaka a 2000-es évek első évtizede volt. Több mint két tucat folyóiratot alapítottak regionális kutatásokkal foglalkozó intézmények, kiadók és intézményi konzorciumok. Kelet- és Közép-Európa legfontosabb regionális tudományi folyóiratainak adatait a 2. táblázat tartalmazza.

A regionális kutatások intézményesültségének foka, hagyományai és kutatói kapacitásai befolyásolják a publikációs aktivitást. A lengyel és a magyar publikációs fórumok összetett képet mutatnak. Ebben a két országban jelenik meg a legtöbb regionális tudományi monográfia is. A magyar Akadémiai Kiadó gondozta a Regionális Kutatások Központja Területi és Települési Kutatások címü sorozatát, amelyben - később más kiadó gondozásában Studia Regionum alcímmel - az elmúlt évtized végéig több mint 40 tudományos monográfia jelent meg a magyar regionális tudományi kutatók eredményeiből. Ezt követően az Akadé- 
2. táblázat: A legfontosabb regionális tudományi folyóiratok jellemzői some characteristics of the major journals in regional science

\begin{tabular}{|c|c|c|c|c|}
\hline Folyóirat címe & $\begin{array}{l}\text { Alapitás } \\
\text { éve }\end{array}$ & Kiadó & $\begin{array}{c}\text { Megjelenés gyakorisága } \\
\text { évente }\end{array}$ & Nyelve \\
\hline \multicolumn{5}{|l|}{ Csehország } \\
\hline Regionalní Studia & 2007 & $\begin{array}{l}\text { Prágai Közgazdaság-tudományi } \\
\text { Egyetem }\end{array}$ & 4 & Angol \\
\hline \multicolumn{5}{|l|}{ Lengyelország } \\
\hline Biuletyn KPZP PAN & 1958 & KPZK PAN & $\begin{array}{l}\text { Eseti, évi 4-5 kötet. } \\
\text { Megjelent } 250 \text { kötet. }\end{array}$ & Lengyel \\
\hline Studia KPZK PAN & 1958 & KPZK PAN & $\begin{array}{l}\text { Eseti, évi } 2 \text { kötet. } \\
\text { Megjelent } 115 \text { kötet. }\end{array}$ & Lengyel \\
\hline Studia Regionalia & 1986 & KPZK PAN & $\begin{array}{l}\text { Eseti, évi 1-2 kötet. } \\
\text { Megjelent } 32 \text { kötet. }\end{array}$ & Angol \\
\hline $\begin{array}{l}\text { Studia Regionalne i } \\
\text { Lokalne }\end{array}$ & 2000 & $\begin{array}{l}\text { Varsói Egyetem Regionális és } \\
\text { Helyi Tanulmányok Központja }\end{array}$ & 4 & Lengyel \\
\hline \multicolumn{5}{|l|}{ Magyarország } \\
\hline Területi Statisztika & 1960 & Központi Statisztikai Hivatal & 6 & Magyar \\
\hline Tér és Társadalom & 1987 & $\begin{array}{l}\text { MTA Regionális Kutatások } \\
\text { Központja }\end{array}$ & 4 & Magyar \\
\hline Falu, Város, Régió & 1999 & $\begin{array}{l}\text { Magyar Regionális Fejlesztési és } \\
\text { Urbanisztikai Kft. }\end{array}$ & 3 & Magyar \\
\hline Discussion Papers & 1986 & $\begin{array}{l}\text { MTA Regionális Kutatások } \\
\text { Központja }\end{array}$ & $\begin{array}{l}\text { Eseti, évi 4-5 kötet. } \\
\text { Megjelent } 105 \text { kötet. }\end{array}$ & Angol \\
\hline \multicolumn{5}{|l|}{ Oroszország } \\
\hline $\begin{array}{l}\text { Region: Ekonomika i } \\
\text { sociologiya }\end{array}$ & 1963 & $\begin{array}{l}\text { OTA Szibériai Tagozat } \\
\text { Közgazdasági és Ipari } \\
\text { Termelésszervezési Intézete }\end{array}$ & 4 & Orosz \\
\hline $\begin{array}{l}\text { Prostranstvennaya } \\
\text { ekonomika }\end{array}$ & 2004 & $\begin{array}{l}\text { OTA Távol-keleti Tagozata } \\
\text { Közgazdasági Intézet }\end{array}$ & 4 & Orosz \\
\hline $\begin{array}{l}\text { Region: sistemy, } \\
\text { ekonomika, upravlenie }\end{array}$ & 2007 & Nauchnaya Zhizn' Kiadó & 4 & Orosz \\
\hline $\begin{array}{l}\text { Regional Science of } \\
\text { Russia }\end{array}$ & 2010 & Springer Verlag & 2 & Angol \\
\hline Ekonomika regiona & 2011 & $\begin{array}{l}\text { OTA Uráli Tagozata Közgazdasági } \\
\text { Intézet }\end{array}$ & 4 & Orosz \\
\hline $\begin{array}{l}\text { Sovremennye } \\
\text { proizvoditel'nye sily }\end{array}$ & 2012 & Termelőerők Kutatási Tanácsa & 4 & Orosz \\
\hline \multicolumn{5}{|l|}{ Románia } \\
\hline $\begin{array}{l}\text { Romanian Journal of } \\
\text { Regional Science }\end{array}$ & 2007 & $\begin{array}{l}\text { Román Regionális Tudományi } \\
\text { Társaság }\end{array}$ & 2 & Angol \\
\hline $\begin{array}{l}\text { Romanian Review of } \\
\text { Regional Studies }\end{array}$ & 2007 & $\begin{array}{l}\text { Babeş-Bolyai Tudományegyetem } \\
\text { Regionális Földrajzi Központ }\end{array}$ & 2 & Angol \\
\hline
\end{tabular}

Forrás: A szerző adatgyüjtése internetes forrásokból. 
miai Kiadó Modern regionális tudomány címü sorozatában jelennek meg a magyar kutatók munkái. Regionális központokban működő, színvonalas lengyel kiadók szép számmal adnak ki regionális tudományi munkákat.

\section{Következtetések}

A társadalmi-gazdasági terekben zajló folyamatok kedvező és negatív hatásai Kelet- és Közép-Európa 20. századi fejlődésében éppúgy megfigyelhetők, mint a kontinens más részein. A területi szempontok a különböző államberendezkedésü korszakok politikáiban is nyomon követhetők. A regionális sajátosságok alkalmazásában a döntéshozókat kutatási eredmények is segítették. A 20. század utolsó évtizedeiben a társadalomtudományok különböző ágainak vizsgálati eredményeit hasznosították a területi jellegü döntések kialakításában. A kommunista korszak hatalmi központjai korlátozottan igényeltek ismereteket a területi folyamatok alakulásáról. A területi kutatások a nemzeti határokon belül zajlottak, a nemzetközi szakmai kapcsolatok - Lengyelország és Magyarország kivételével - gyengék és alkalmiak voltak.

A rendszerváltozást követően a piacgazdaság kiépülése mély regionális átalakulást indított el. A változások irányíthatósága miatt természetes igényként fogalmazódott meg a területi kutatások tematikai és szervezeti fejlesztése egyaránt. Az európai uniós csatlakozás előkészítése újabb impulzusokat adott a kutatásoknak. A 21. század elején valamennyi országban bővültek a nemzeti regionális kutatás műhelyei. A kutatások volumenében, intézményi berendezkedésében és területi elhelyezkedésében különbségek figyelhetők meg. Két uniós tagországban - Lengyelországban és Magyarországon -, valamint Oroszországban kellő mennyiségben fellelhetők mindazok az elemek, amelyek a regionális tudományt önálló tudományágazatként jelenítik meg (3. táblázat). A többi országban a diszciplináris ismérvek egy része hiányzik vagy gyenge fejlettséget mutat.

A regionális tudományi kutatóhelyek decentralizáltabb területi elhelyezkedésűek, mint a tudomány más ágazatai. A kelet- és közép-európai országok kutatás-fejlesztési kapacitásai magas fővárosi koncentrációt mutatnak, ezt a tudományos és a regionális fejlődés szempontjából kedvezőtlen jelenségnek kell tekinteni (Horváth 2009). Lengyelországban, Magyarországon és Romániában a fővárosi régiók súlya a regionális tudomány foglalkoztatottainak számát tekintve fele-harmada a más tudományágazatokban tapasztaltaknak. A regionális tudomány a társadalmi tevékenységek decentralizálásának jelképe és követendő példája. E tudományágazat értékes tapasztalatokkal rendelkezik a decentralizált és hálózatos szervezetrendszer működtetésében, módszereinek alkalmazása a gazdaság és társadalom más szféráiban is eredményes lehet.

A regionális kutatások fejlődéstörténetét vizsgálva azt tapasztaltuk, hogy a tudományágazat fellendülésében, a kutatási innovációk széles körű hasznosítá- 
3. táblázat: A regionális tudomány diszciplináris ismérveinek fejlettsége The state of development in disciplinary criteria of regional science

\begin{tabular}{|c|c|c|c|c|c|c|c|}
\hline Megnevezés & Bulgária & Csehország & Lengyelország & Magyarország & Oroszország & g Románia & Szlovákia \\
\hline Kutatóhelyek & - & +1 & m & 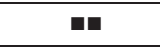 & 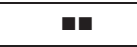 & - & - \\
\hline $\begin{array}{l}\text { Egyetemi mester- } \\
\text { szakok }\end{array}$ & & mII & min & 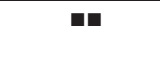 & $\square$ & - & - \\
\hline Doktori iskolák & & & "ח & 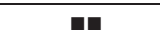 & m & & \\
\hline Folyóiratok & & - & ח & m & m & - & \\
\hline Könyvsorozatok & & & m & m & $\square$ & & \\
\hline $\begin{array}{l}\text { Tudományos társa- } \\
\text { ság és tudományos } \\
\text { akadémiai koordi- } \\
\text { nációs szervezet }\end{array}$ & & & 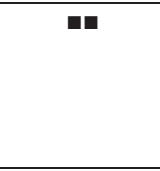 & $\square$ & 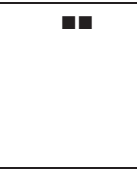 & - & \\
\hline $\begin{array}{l}\text { Nemzetközi regio- } \\
\text { nális tudományi } \\
\text { kongresszus }\end{array}$ & & - & ma & mI & - & - & $\square$ \\
\hline
\end{tabular}

Jelmagyarázat: $\mathbf{\square}=$ Gyengén fejlett; $\mathbf{\square}=$ = Fejlett .

sában kitüntetett szerepük van kiemelkedő tudósegyéniségeknek. Lengyelországban Antoni Kuklińskinak (1927-), a Varsói Egyetem professzorának közreműködésével jött létre a regionális tudomány számtalan orgánuma és intézménye. Oroszországban az elmúlt két évtizedben Alekszandr Granberg (1936-2010) akadémikus - előbb a novoszibirszki közgazdasági intézet igazgatója, majd a Termelőerők Kutatási Tanácsának elnöke - fejtett ki jelentős munkát az orosz regionális tudomány fejlesztése érdekében. Magyarországon Enyedi György (1930-2012) akadémikus teremtette meg ezt a tudományágazatot. Mindhárman sokat tettek azért is, hogy a kelet- és közép-európai kutatási eredmények beépüljenek a regionális tudomány nemzetközi rendszerébe.

\section{Köszönetnyilvánítás}

A tanulmány az Új térformáló erők és fejlődési pályák Kelet-Európában a 21. század elején című OTKA-kutatás (témaszám: 104985) keretében készült.

\section{Irodalom}

Adamesku, A. A. (2012): K 100-letiju Szovjeta po izucseniyu proizvoditel'nüh szil. http://www.sops.ru/sops/ istoriya (Letöltés: 2012. november 10.) 
Artobolevsky, S. S. (1997): Regional policy in Europe. Jessica Kingsley, London Benko, G. (1999): Regionális tudomány. Dialóg Campus Kiadó, Budapest, Pécs

Bihari O. (1983): Korszerủ tendenciák az államhatalom gyakorlásában. Közgazdasági és Jogi Könyvkiadó, Budapest

Boyce, D. (2004): A short history of the field of regional science. Papers in Regional Science, 1., 31-57.

Boyce, D., Nijkamp, P., Shefer, D. (1991): Regional science: retrospect and prospect. Springer-Verlag, Berlin

Bradshaw, M. J. (1993): The economic effects of Soviet dissolution. Royal Institute of International Affairs, London

Bradshaw M. J., Stenning A. C. (eds.) (2004): The post socialist economies of East Central Europe and the former Soviet Union. Pearson, DARG, Harlow

Czirfusz M. (2012): A térszemlélet szerepe a regionális tudomány, a gazdaságföldrajz és a közgazdaságtan viszonyában. In: Rechnitzer J., Rácz Sz. (szerk.): Dialógus a regionális tudományról. Széchenyi István Egyetem Regionális és Gazdaságtudományi Doktori Iskolája, Magyar Regionális Tudományi Társaság, Győr, 52-59.

Dergacsev, V. A., Vardomszkij, L. B. (2010): Regionovedenie. Uniti, Moszkva

Domański, R. (1983): Gospodarka przestrzenna. PWN, Warszawa

Dziewoński, K. (1967): Teoria regionu ekonomicznego. Przegląd Geograficzny, 1., 33-50.

Egyed I. (2012): A regionális tudomány az elmélet és a a gyakorlat között. Tér és Társadalom, 4., $17-36$.

Enyedi Gy. (1981): Földrajz és társadalom. Magvető Könyvkiadó, Budapest

Enyedi Gy. (1989): Településpolitikák Kelet-Közép-Európában. Társadalmi Szemle, 10., 20-31.

Enyedi Gy. (2003): Alkalmazott földrajz Közép-Európában. Földrajzi Értesitő, 3-4., 145-160.

Florax, R. J., Plane, D. A. (eds.) (2004): Fifty years of regional science. Springer-Verlag, Heidelberg, New York

Gorzelak, G. (1996): The regional dimension of transformation in Central Europe. Jessica Kingsley, London

Hamilton, I. F. E. (1974): Poland's Western and Northern territories. Oxford University Press, Oxford

Hamilton, I. F. E. (1982): Regional policy in Poland. A search for equity. Geoforum, 2., 121-132.

Horváth Gy. (2004): Regionális egyenlőtlenségek Európában. Magyar Tudomány, 9., 962-977.

Horváth Gy. (2008): Regionális átalakulás Oroszországban. In: Horváth Gy. (szerk.): Regionális fejlődés és politika az átalakuló Oroszországban. MTA Regionális Kutatások Központja, Pécs, 11-62.

Horváth Gy. (2009): Regionális egyenlőtlenségek a kelet- és közép-európai kutatási térségben. Magyar Tudomány, 12., 1499-1512.

Illés I. (2002): Közép- és Délkelet-Európa az ezredfordulón. Átalakulás, integrációk, régiók. Dialóg Campus Kiadó, Budapest, Pécs

Ioffe, G. V., Nefedova, T. G. (2000): The environs of Russian cities. A case study of Moscow. Russian views of transition in the rural sector. The World Bank, Washington

Isard, W. (1975): Introduction to regional science. Prentice-Hall, Englewood Cliff

Isard, W. (ed.) (2003): History of regional science and the Regional Science Association International. Springer-Verlag, Berlin, Heidelberg, New York

Isserman, A. M. (1993): The history, status and future of regional science: an American perspective. International Regional Science Review, 2., 249-296.

Isserman, A. M. (1995): Lost in space? On the history, status, and future of regional science. Review of Regional Studies, 1., 1-50.

Kotljakov, V. M., Glezer, O. B., Trejvis, A. I., Svecov, A. N. (2012): Novaja programma fundamental'nüh isszledovanij prosztransztvennogo razvitija Rosszii. Region: Ekonomika i szociologija, 2., 24-44.

Krugman, P. (1991a): Geography and trade. MIT Press, Cambridge

Krugman, P. (1991b): Increasing returns and economic geography. Journal of Political Economy, 3., 483-499.

Krugman, P. (2000): A földrajz szerepe a fejlödésben. Tér és Társadalom, 4., 1-21.

Krugman, P. 2011: The new economic geography, now middle-aged. Regional Studies, 1., 1-7.

Kukliński, A. R. (1966): Research activity of the Committee for Space Economy and Regional Planning. In: Fisher, J. C. (ed.): City and regional planning in Poland. Cornell University Press, 
Ithaca, 389-405.

Kulcsár K. (1986): A modernizáció és a magyar társadalom. Tanulmányok. Magvető Könyvkiadó, Budapest

Kulesov, V., Szeliversztov, V., Suslov, V., Suspicyn, S. (2012): Szibirskaja skola regional'nüh isszledovanij v programme Prezidiuma RAN „Fundamental'nüe problemü prosztransztvennogo razvitija Rosszijszkoj Federacii: mezsdiszciplinarnüj szintez". Region: Ekonomika i szociologija, 2., $3-23$.

Lappo, G. M., Hönsch, F. W. (2000): Urbanisierung Russlands. Urbanisierung der Erde. Gebrüder Borntraeger, Berlin, Stuttgart

Lieven, D. 2000: Empire: the Russian Empire and its rivals. New Heaven, London

Malisz, B. (red.) (1978): 40 lat planowania struktury przestrzennej Polski. Studia Komitetu Przestrzennego Zagospodorowania Kraju. LXIV

Martin, R. (1999): The new "geographical turn" in economics: some critical reflections. Cambridge Journal of Economics, 1., 65-91.

Maurel, M.-C. (1982): Territoire et stratégies soviétiques. Economica, Paris

Maurel, M.-C. (2002): Central-European geography and the post-socialist transformation. A Western point of view. In: Kaase, M., Sparschuh, V., Wenninger, A. (eds.): The social science disciplines in Central and Eastern Europe. Handbook on economics, political science and sociology. GESIS, Social Science Information Centre, Collegium Budapest Institute for Advanced Study, Bonn, Berlin, Budapest, 578-587.

Maurel, M.-C. (2004): Différenciation et reconfiguration des territoires en Europe centrale. Annales de géographie, 2., 124-144.

Mészáros R. (2006): A társadalomföldrajz és a regionális tudomány Magyarországon. Magyar Tudomány, 1., 21-28.

Musil, J. (1977): Urbanization in Socialist countries. Svoboda, Praha

Nemes Nagy J. (1998): A tér a társadalomkutatásban. Hilscher Rezső Szociálpolitikai Egyesület, Budapest

Rey, V., Gerbaud, F. (1996): Nouvelles campagnes de l'Europe Centre Orientale. Espaces \& milieux. CNRS, Paris

Székely Kongresszus. Hargita Kiadóhivatal, Csíkszereda, 2001

Tarhov, S. A. (2005): Dinamika adminisztrativno-territorialnogo delenija Rosszii v XX veke. In: Glezer, O. B., Poljan, P. (red.): Rosszija i ee regioni v XX veke: territorija - rasszelenie - migracii. OGI, Moszkva, 33-75.

Trejvis, A. (2002): Promüslennoszt' v Rosszii za 100 let. In: Danilova-Daniljana, V. I., Sztepanova, S. A. (red.): Rosszija v okruzsaiuscsem mire: 2002. Analiticseskij ezsegodnik. Izdatel'sztvo Mezsdunarodnogo nezaviszimogo ekologo-politologicseskogo universiteta, Moszkva, 1-12.

Turnock, D. 1978: Eastern Europe. Dawson Publishing, London (Studies in Industrial Geography)

Turnock, D. 1989: The human geography of East Central Europe. Routledge, London. 